\title{
An Ecofeminist Reading of Salwa Bakr's "Thirty-One Beautiful Green Trees "and "Worms at the Flower Garden"
}

By

\author{
Ebtesam M. El Shokrofy ${ }^{*}$
}

\begin{abstract}
Ecofeminism combines ecology and feminism in one movement to show the positive relationship between women and nature. The more empowered women become, the better nature gets, and vice versa. In other words, ecofeminism calls for more empowerment of women by analysing the correlation between the negative human impact on the natural world and the oppression of women. Ecofeminists such as Mary Mellor, Greta Gaard, Carolyn Merchant, among others, conclude that both nature and women are exposed to many kinds of violence in patriarchal societies. Thus, in order to free nature, we need to empower women first. Since ecofeminism is not only a theory but a way of life as well, literature is one of the most suitable medium to convey its message. The aim of this paper is to show how literature mirrors the message of ecofeminism. By reading Salwa Bakr's two short stories, "Thirty-one Beautiful Green Trees" and "Worms at the Flower Garden", the researcher believes that Mary Mellor's ecological point of view would be applicable.
\end{abstract}

Keywords: Ecofeminism, Mary Mellor, Salwa Bakr, "Thirty-one Beautiful Green Trees" and "Worms at the Flower Garden"

\footnotetext{
* Associate Professor of English Literature - Faculty of EducationDamanhur University
}

(An Ecofeminist Reading of Salwa Bakr's...) Dr. Ebtesam El Shokrofy 


\section{Ecofeminism: Definition and Approach}

The term "ecofeminism", as it is widely known, was first coined by the French feminist Francois d'Eaubonne in 1974. Different approaches to both the association of women with nature as well as the analysis of women's oppression have emerged. Liberal, cultural, social, and socialist movements, all provide strong evidences for the deep connection between nature and women- and hence, the connection between the domination of women and the domination of nature - but in different perspectives. All approaches agree that all humans, men and women, should do their best to save the environment from the destruction and violence practiced by some humans. Sociologist Mary Mellor makes a reasonable compromise out of all these different approaches. She puts seven grounds for her approach which she calls a 'materialist ecofeminist approach'. Before discussing Mellor's theory, a brief analysis of the various approaches of ecofeminism should be tackled.

Liberal ecofeminists maintain that the solution to the problems of the environment lies in the application of science and technology, as well as the passage of new laws and regulations. Liberalism calls for the betterment of the whole society and sees that "all humans possess the same nature as free and rational beings. Accordingly, any unequal treatment towards women would deny this moral equality and would therefore be unjust" (Merchant 57). Cultural ecofeminism sees the relation between women and nature as a biological one. Cultural ecofeminists claim that in prehistory, "nature was symbolized by pregnant female figures, trees, butterflies, and snakes and in which women were held in high esteem as bringers forth of life"(Merchant 191).Thus, cultural

(An Ecofeminist Reading of Salwa Bakr's...) Dr. Ebtesam El Shokrofy 
ecofeminists see that the power of women lies within their deep association with the power of nature. Cultural ecofeminists accuse the scientific revolution of creating a mechanic male-dominated society. A recent study on cultural ecofeminism examines two ways in expressing the relation between women's culture and ecological concerns. Cultural ecofeminists are concerned with "an ecological ethics based on care and relationships and a women's spirituality movement. Care ethics means moral universe in which cooperation replaces conflict, relationship replaces confrontation and caring for others replaces rights and duties" (Kalita 59). For cultural ecofeminists, women's spirituality is the other form of connection between women and nature.

For social ecofeminists, women's oppression is a direct result of a web of social relationships which include both the economic and the traditional patterns of gender role. To get their freedom and rights, women should be liberated from economic and social oppression by having an effective role in their own lives. To the same effect, Carolyn Merchant contends that the domination of nature is built on the domination of human by human. To free both land and human, all forms of dominance and oppression should be ended. It is true that there are biological differences between women and men, but this is not a ground of dominance nor oppression. A life of cooperation, mutual love and communal responsibilities should replace struggles, conflicts, dominance, and oppression.

Socialist ecofeminism provides new perspectives. It sees that reproduction is the key of a happy and just society. It focuses on the reproduction of life itself. Socialist

(An Ecofeminist Reading of Salwa Bakr's...) Dr. Ebtesam El Shokrofy 
ecofeminists contend that our existence depends on the existence of nonhuman life. Therefore, we should do our best to protect it. "Nature and human nature are socially and historically constructed over time and transformed through human praxis. Nature is an active subject, not a passive object to be dominated, and humans must develop sustainable relations with it"(Merchant 196). This means that women are more careful about nature and the environment, thanks to the deep long relations between the two of them: "As gatherers of food, fuel, and medical herbs; fabricators of clothing; planters, weeders, and harvesters of horticultural crops; tenders of poultry; preparers and preservers of food; and bearers and caretakers of young children, women's intimate knowledge of nature has helped to sustain life in every global human habitat". (Merchant 197). Gradually, with specialized and mechanized agriculture in colonial and capitalist societies, men's farming roles are foregrounded while women are backgrounded to housework. Merchant goes on adding that middle-class women's roles shifted from production to the reproduction of daily life in the home, focusing on increased domesticity and the bearing and socialization of young children. Thus, women begin to lose their financial independence gradually.

\section{Mary Mellor and Women's Oppression}

However different their views are, liberal, cultural, social and socialist ecofeminists agree that there is a deep relation between women and nature, and that the oppression of women is parallel to the destruction and misuse of nonhuman nature in male-dominated cultures. Sociologist Mary Mellor does not only provide a compromise of all these views, but also advocates an approach of hers, followed by

(An Ecofeminist Reading of Salwa Bakr's...) Dr. Ebtesam El Shokrofy 
many others- the materialist ecofeminists. According to Armbruster, Mellor provides "an excellent overview of the many strands of thought contributing to the current body of ecofeminist theory...Mellor makes an especially important contributions to conversations not just about ecofeminism, but about all human relationships to nature"(212-13). This approach is based on seven statements forming the theoretical part of this paper, which, in turn, will be applied to the two selected short stories. The seven statements are mediation, immanence, equality, co-operation, sex/gender division, ecological holism, and change. Throughout her work, Mellor advocates herself to write not only about ecofeminism, but also about all human relations to nature. She begins her article, "Feminism and Environmental Ethics: A Materialist Perspective" by summarizing the common grounds of her approach. She agrees that women's lives in a gendered society are grounded in the materiality of existence, and that a "solution to the questions of environmental ethics needs to start from an understanding of the social relations underpinning current patterns of unsustainability together with an understanding of the material relations between humanity and nature"(108). She calls for a link between social and ecological relations on the ground that the relationship between humanity and nature is based mainly upon the relations between human and human. Ecofeminists and ecologists both agree that the orientation of the natural world should be viewed within a socioeconomic context. In addition, gender inequality depends also on the relationship between humanity and nature.

Mellor, then, moves on to discuss her seven materialist ecofeminist grounds in detail. First, she begins with the relationship between women and nature. After

(An Ecofeminist Reading of Salwa Bakr's...) Dr. Ebtesam El Shokrofy 
discussing the different approaches of ecofeminism and their various views about the relationship between women and nature, be it biological, social, cultural, among many others, Mellor adopts a middle ground which she calls mediation. For her, the sex/gender inequality causes a material relation of inequality between dominant men and subordinate women. Women are materially placed between 'Man' and 'Nature'. They act as mediators of human nature relations. Being mediators means making time, space, or resources for someone else. This involves both exploitation and exclusion. Materialist ecofeminism is concerned with the way male domination is created and sustained. Mellor gives an example of this exploitation- the exploitation of women's work without reward and the idea of their availability.

Being mediators does not negate the fact that sometimes women themselves are the "beneficiaries of mediation". Women mediate biological time for their families, but at the same time they exploit the labor and resources of others. Mellor adds, "Many people live in complex networks of mediation on the basis of race, class, gender, or ethnicity...The needs of human embodiment are shared by all hu(man)ity but are disproportionately borne in the bodies and lives of women"("Feminism and Environmental", 113-14). This is women's permanent role in some societies - caring for and nourishing the bodies of others whether in a paid or unpaid capacity. Mellor calls it immanence, the second central concept of materialist ecofeminism. Women are doomed to such roles both biologically and physiologically. In addition, and more importantly for Mellor, is that women are linked to nature due to the social circumstances in which they find

(An Ecofeminist Reading of Salwa Bakr's...) Dr. Ebtesam El Shokrofy 
themselves. There are social activities imposed on women in male-dominated societies.

Such domination should end so that women could feel equal. Equality is the third requirement of ecofeminists. There will be no hope for women's liberation nor solutions to the ecological crisis unless the concept of domination ends. Basically, the idea of the domination of nature starts with the social domination between masters and servants as well as men and women. Dominance creates destruction and damage. Many world problems such as war, hunger, oppression, shortages of natural resources, over populations are direct results for the need of power and control. Instead, a fourth approach of co-operation and understanding should be followed. Mellor adds:

Men and women can adopt a suitably earth-centered approach...From a materialist ecofeminist perspective I would argue for an approach starting from sex/gender dualism as a relation of (re) production. This reflects a material necessity rather than a cultural/philosophical construction. In all human societies the need exists to construct the social within the constraints of the agency of the natural. This is exacerbated by the dualist and sexist structures of western society. ("Feminism and Environmental", 111)

Accordingly, a fifth approach of the sex/gender division of labor around human embodiment should be discussed. For years, as Mellor states, feminists have fought

(An Ecofeminist Reading of Salwa Bakr's...) Dr. Ebtesam El Shokrofy 
and opposed the idea of women's association with human embodiment whether as paid or unpaid work, even their 'natural' work of mothering, nurturing, and caring. In traditional societies, men have spent their time in trade, war and politics while women have been tied to their biological time - the life cycle and rest/renewal time-scale of the human being. The centrality of women's socioeconomic position in this relationship is her responsibility for biological time. Recently, ecofeminists, in general, and cultural ecofeminists, in particular call for the evaluation of women's work on the grounds of knowledge and skill, not on biological grounds. In industrial societies, the image of man is that of the economic man who is "young, fit, ambitious, mobile, an unencumbered by obligations". At the very same time, women are still "circumscribed by obligated labor performed on the basis of duty, love, violence, or fear of loss of economic support". Mellor adds that in order to take their place in the western public world, "women have to present themselves as autonomous individuals, 'honorary men' avoiding domestic obligations, undertaking them in their 'free time', or paying someone else to carry out that work" ("Feminism and Environmental", 113).

Sex/gender labor division is considered a form of women's oppression. In tribal societies, women hold a highly economic position being a partner in economic communities through their work as food gatherers, gardeners, clothes makers, and cooks, among many others. Their work was complementary to men's activities of hunting, fighting, and ruling. Despite being excluded from political life, women were luckier in tribal societies than during the periods of urbanization and industrialism; they lost their economic power and independence. Mellor adds:

(An Ecofeminist Reading of Salwa Bakr's...) Dr. Ebtesam El Shokrofy 
Urbanism separates women from their independent agricultural work. Industrialism completes the process by separating work and home. For poor women, there was no choice but to follow the work to the factories where organized male unions(eventually) pushed them into the most exploited areas of work on menial wages...left in the home, bourgeois women's only career became child rearing, and the birth rate for all women rose rapidly...middle-class women also became responsible for domestic labor. With very little else to do, the domestic woman becomes symbolized by her sex, and femininity became a career. ("New Woman", 300)

This is a world problem, which is called "ecological holism" or universality, according to Mellor's sixth ground. Ecological holism means that the whole is always more than the sum of its parts, that individual actions affect the whole society. Thus, women 's lives, and experience are likely to be more relevant to ecological sustainability. Ecological holism means that we are not an isolated civilization; we are connected to the rest of the world in one way or another. This mutual relation creates a stronger relation of cause and effect.

Mellor 's seventh statement is change. It means that a solution to the problems of women and nature should be provided. According to Mellor, a social revolution is a must for both women's liberation and the problems of ecological destruction. This revolution requires a transformation of the

(An Ecofeminist Reading of Salwa Bakr's...) Dr. Ebtesam El Shokrofy 
relationship among power, work, and home. She calls for technological rationality as "the highest gift of nature that has been misused by ruling- class domination". Moreover, Mellor identifies three areas of change:

The most obvious is the plant's own response to human action. The ecological effects of human action such as ozone depletion and global warming, unlike desertification and localized pollution, affect the dominant as well as the subordinate. Another locus of struggle are the campaigns by those who are subject to social and environmental injustice. Desertification, commercialization of land, destruction of local habitat, all produce economic and social dislocation and political responses such as land claims which the so-called 'developed' world is finding increasingly difficult to ignore. ("Feminism and Environmental", 121)

This change lies in a joint effort of both the individuals and the community. Individuals should alter their ideas and practices towards themselves and nature. They should be convinced that change is a must for everyone's sake. People should trust their communities more and believe that community is a system of cooperation for the betterment of all rather than competition for the success of a few. In turn, governments pass strict laws and encourage, if not force,

(An Ecofeminist Reading of Salwa Bakr's...) Dr. Ebtesam El Shokrofy 
people to change their needs and desires. Without these joint efforts, no solutions will be effective.

\section{Ecofeminism and Literature}

Change is mostly carried through literature. Literature is the most suitable medium of conveying the messages of ecofeminism as a way of life. Literature deepens the sense of conversion - a person by person, thought by thought, action by action. It provides live human experiences enabling readers to open platforms of discussions leading to actions. Literature teaches people the importance of the interconnectedness in life, of the universal holism, and of the necessity of taking responsibility for the consequences of their choices and actions. This paper will apply the aforementioned theoretical framework to the work of the Egyptian novelist and short story writer Salwa Bakr.

Salwa Bakr was born in 1949 to a lower-middle-class family in Cairo. The family forms Baker's personality and later affected her writings. Born as an orphan, for her father died before her birth, Bakr has presented most of her heroines as emotionally deprived of the father's love and care. The father is always absent and has no role and scarcely mentioned in "Thirty-one Beautiful Green Trees". By the same token, the father is never mentioned in "Worms at the Flower Garden", which justifies- partially- the heroine's deep attachment to trees and flowers as emotional substitutions. Bakr's poor and uneducated mother deepens Bakr's feeling of the importance of education at an early age. She obtained a bachelor's degree in Business management in 1972, followed by another one in Theatre in 1976. Bakr practiced free reading in literature, law, history, and music which shaped her writings that exceed twenty, above all short story

(An Ecofeminist Reading of Salwa Bakr's...) Dr. Ebtesam El Shokrofy 
collections and novels. By 1980s, Bakr has become one of the most prominent female writers in the Egyptian and Arab literary scene. Most of her work has been translated into English. In 2006, Bakr's two short stories, “The Beautiful Undiscovered Voice" and "Thirty-one Beautiful Green Trees" have been dramatized by the American playwright Yussef EL Guindi into Such a Beautiful Voice is Sayeda's and Karima's City, respectively.

In an industrialized world that cares nothing about the importance of the greenness and the beauty of nature, only Karima and Farha in "Thirty-one Beautiful Green Trees" and "Worms at the Flower Garden", respectively, do stand strongly calling for action to stop damaging the environment. Unfortunately, they are accused of madness and taken to an asylum at the end. Karima gets shocked, one day going to her work, to see the massacre of the thirty-one green trees she used to see daily. Her sadness over the destruction of the city and her inability to save nature from the brutality of humankind turns her into a social misfit and thus, labeled mad. By the same token, Farha in "Worms at the Flower Garden" is horrified upon the loss of natural beauty around her. Her continuous disgust over the brutal consuming society turns into a daily nightmare symbolized by the appearance of worms ending up beauty.

Bakr's concern with beauty and the necessity to live in a beautiful world is a recurrent theme in most of her works. In these works, as Rasheed El-Enani states:

Beauty as a life value is important in Bakr's worldview. It is a somewhat fluid concept but persistent in her work. Female beauty does not come into the

(An Ecofeminist Reading of Salwa Bakr's...) Dr. Ebtesam El Shokrofy 
equation: this, as repeatedly shown in her work, is a value of patriarchal society and is much lamented as a bio-social predestination of women who do not live up to the male criteria, and a further demonstration of the imbalance in social attitudes, since men are not subject to any such physical criteria. What she strives for appears to be an aesthetic sense of life in general that encompasses everything from urban environment...to an appreciation of the arts and finer things of life... Time and again her characters are chagrined at the disappearance of the value of beauty from society. (392-3)

El-Enani's abovementioned quotation summarizes the cornerstones of this paper. First, it sheds light on the relationship between women and nature, as represented in Bakr's works, and how this relation affects women's social, economic, and political life. Second, it gives the reader the chance to relate Bakr's works to ecofeminism in general and Mellor's views, in particular.

In her writings, Bakr reflects the views of cultural and social ecofeminists who see that women are imprisoned inside certain biological and social roles. Bakr asserts that women's dilemma rests on the gap/ opposition between women's actual position in society and society's expectation of them. Women are still imprisoned by the old idea that they create life; pregnancy, childbirth, child rearing and family care while as men create history and dominate social and political life. Nowadays, even though women are given more

(An Ecofeminist Reading of Salwa Bakr's...) Dr. Ebtesam El Shokrofy 
rights and become more active in different spheres of life, they are still looked upon within their traditional roles as daughters, wives, and mothers.

As a daughter, Karima in "Thirty-one Beautiful Green Trees" is imprisoned by the male-dominated society both at home and work. At home, her mother always favors her brother for nothing but being a man. One day, the mother threatens Karima of cutting her tongue because she tells her father that her younger brother has broken a vase. Later on, when Karima expresses her political views frankly, her mother rebukes her saying, "Has it come to this? How could you jeopardize your brother's future? Don't you know that he is an officer; that your behavior might force him to give up his career? Won't you stop this frivolity and shut up for good? By God, you deserve to have your tongue cut out" (Bakr 133). With the absence of the father and the prejudice of the overburdened mother, Karima is left marginalized. Karima's family is just an example of those families who fail to understand the personal problems of the female protagonists. Instead of addressing these problems, the families force their daughters into a mental asylum "so that they can avoid their retaliatory hostility and disruptive presence in their lives" (Sinno 70). The attempt to silence Karima at home extends to her work. Feeling bored with the dull grey desks around her at work, Karima thinks to turn hers into a brighter color- red. To her surprise, the security guard, ordered by the manager, refuses to let the vendor in, on the ground that this action is a social misfit. Another example of misfit occurs when Karima, being late for work, forgets to put on her bra. Upon seeing her so, the manager, the senior and everyone else accuse her of being mad and abnormal.

(An Ecofeminist Reading of Salwa Bakr's...) Dr. Ebtesam El Shokrofy 
The control practiced over Karima's mind and body is an example of a male- dominated society, something that is totally rejected by ecofeminists. The bra symbolizes "male control over female sexuality and its absence threatens the status quo and accounts for the exaggerated reaction of Karimah's boss" (Manisty 159). This 'pre-assigned social role based on gender extends to politics. On her way back from work on the day of the public election, Karima is stopped by a group of people who give her some papers and ask her to cast her voice for their party. Instead, Karima begins to read the papers carefully inquiring about the candidates and the efforts they should exert for the benefits of the whole society. Karima asks the candidates to provide their own agenda and the grounds upon which she would elect them. Suddenly, Karima surprises everyone by her daring direct questions:

Is your party striving to plant trees rather than cement in the city? Has it organized an armed force to destroy weasels effectively? Does it possess a potion capable of restoring joy to my heart? ...You're a useless lot, all of you, with those flabby bodies of yours: A healthy mind is in a healthy body. Most of our ministers are ugly, with such fat necks it makes you doubt their ability to do anything useful...Where are the women?! I don't see any women about! Why don't you find out the reason for the flight of birds from our city, for the increase in the number of flies and mosquitoes? (Bakr 132-3)

(An Ecofeminist Reading of Salwa Bakr's...) Dr. Ebtesam El Shokrofy 
Karima's abovementioned words shed light on the two main cornerstones of this paper - feminism and ecology.

Concerning feminism, the quotation supports the old patriarchal and the conservative attitudes towards women. These attitudes have long been secured by the limitation of the roles of women and become endangered now by women's new awareness of themselves and their rights of education, work, and independence. The louder the calls of the patriarchal societies to suppress women and limit their political/social roles in public life are heard, the stronger voices of women's resistance get. This situation is the turning point in the story, as Badry puts it; "The situation escalates on the day of election when she dares to ask the candidates about their ecological program and about the lack of women candidates. As a result, her identity and voter's registration card are taken, and she is attacked" (10).

Regarding ecology, Karima's words reflect women's concern with nature and environment. Karima's repeated words about planting trees, getting rid of weasels, empowering women, restoring birds to the city, fighting flies and mosquitoes and having clear effective plans for better future, all relate Karima to ecofeminists in general, and to the Chipko movement, in particular. Merchant defines Chipko movement as follows:

It has its historical roots in ancient Indian cultures that worshipped tree goddesses, sacred trees as images of the cosmos, and sacred forests and groves. The earliest woman - led tree-embracing movements are three-hundred years old. In the 1970s women revived these Chipko actions in

(An Ecofeminist Reading of Salwa Bakr's...) Dr. Ebtesam El Shokrofy 
order to save their forests for fuel wood and their valleys from erosion in the face of cash cropping for the market. The basis of the movement lay in a traditional ecological use of forests for food (as fruits, roots, tubers, seeds, leaves, petals, and sepals), fuel, fodder, fertilizer, water, and medicine. Cash cropping by contrast severed forest products from water, agriculture, and animal husbandry... (201-2)

All these efforts to save the environment and the beauty of nature are echoed again by Farha in "Worms at the Flower Garden". Farha, like many other ecofeminists worldwide, pleas for the value of beauty and the continuation of life on earth. This is exactly what Mellor termed as "ecological holism". Following are examples of women efforts to protect nature all over the world:

In Kenya, women of the Green Belt movement band together to plant millions of trees in arid degraded lands. In India, they join the Chipko (tree- hugging) movement to preserve precious fuel resources for their communities...In Canada; they take to the streets to obtain signatures opposing uranium processing near their towns. In the United States, housewives organize local support to clean up hazardous waste sites. (Merchant 183)

(An Ecofeminist Reading of Salwa Bakr's...) Dr. Ebtesam El Shokrofy 
In Egypt, Farha tries to convince everyone that they should change their lifestyle in order to lead a meaningful life. Farha likens her life and the life of her folks to worms: they just eat, drink, sleep, reproduce, die, and nothing more. Farha's dreams of change, which are the core of the story, represent the dreams of all ecofeminists. In her article, "New Woman, New Earth", Mellor, following Rosemary Ruether, calls for a universal change towards our attitudes to nature, "a change in human consciousness, a historical project and struggle of re-creation that will remake humanity's relation with nature"(304). Farha, as many of Bakr's female characters, dreams of a better life, not only for females but also for the whole community. Like many of Bakr's heroines, Farha is concerned with the importance of beauty in a society that is deaf to all her pleas, a society "That is so driven by the necessity of mere survival that it has no time for beauty"(ElEnani 396). Having problems with her family, colleagues and all the people around her, Farha feels lonely and escapes into herself. Her bright dream turns into a gloomy nightmare where all people are metamorphosed in her eyes into worms. Each night she has a nightmare of worms eating their way in a flower garden.

Bakr shifts from using first person narration in "Thirty-one Beautiful Green Trees" to the third person in "Worms at the Flower Garden". Such a technique enables her to "focus upon the detail of everyday life as it is experienced by Egyptian women, and they express her discontent with the cultural attitudes, social institutions and economic policies that shape women's lives"(Seymour 151). Farha begins by telling her own suffering inside her family. As an unmarried middle-class woman, Farha, like Karima, is entrapped within a net of social conventions and customs that force her to

(An Ecofeminist Reading of Salwa Bakr's...) Dr. Ebtesam El Shokrofy 
submit to the male-dominated society. When Farha refuses to go with her family to a summer resort preferring to be home alone, she is reminded by her mother's words: "After all, you are only a girl". When Farha refuses a suitor because she does not like him, her aunt rebukes her saying, "Men were not valued by their looks but by the money in their pockets" (Bakr 78). Farha's aunt summarizes the issue of rising consumerism in Egypt during the postcolonial period. At that time, wealth, advanced technology, and western products are the standards of a good lifestyle, as Finzer states, "With the accumulation of wealth as an ideal, the have-notes become especially susceptible to pursuing wealth at any cost, including the compromise of personal values, safety and communal welfare' (74).

Farha's problems result from the sharp contrast between her sense of beauty and the ugliness of her community. This contrast is a major concern for Bakr, who is "horrified at the absence of beauty from people's life. To her, the harshness of life is a cobweb of official corruption, social injustice, and ingrained unfair social traditions, but also the vulgarity of taste and crudeness of lifestyle"(El-Enani 392). Farha is upset with her family's lifestyle especially their overeating. In one situation, Farha reports how her family gathers at lunchtime to eat fish. She bitterly describes them as follows:

Their fat bodies showed opulent bellies, in varying sizes, and their swollen faces had meaningless, flabby eyes. They looked like real corpses that had reached a point of maximum inflation before going rotten. Laid out in front of them

(An Ecofeminist Reading of Salwa Bakr's...) Dr. Ebtesam El Shokrofy 
was a huge amount of fried and grilled fish. They reached out and with their fingers severed their little heads, ripped open their stomachs and devoured their flesh, leaving behind their fragile bones and their little eyes staring in the void. They kept on sipping their drinks and recalling various memories of eating fish (Bakr 76-7).

The disgusting images of fat bodies with opulent bellies, corpses, rotten, severed heads, ripped stomachs; among many others, devour Farha's soul making her vomit and faint. Farha's call to stop overeating non-human species echoes "Western vegetarian ecofeminism that eating meat can be seen as a form of cannibalism, particularly for those who reject the human/ non- human animal dualism" (Gaard 652).

Eating meat is used repeatedly in "Worms at the Flower Garden" to highlight the brutal massacre of natural resources. No sooner have Farha's family finished their breakfast than they started to choose between grilled meat with baked potatoes, or lamb meat stew with rice and bread, as their lunch. Overeating, generally, reflects the lack of an aesthetic sense of life. One day, Farha's aunt visits them with some butter pastries with honey. The aunt suggests that they all eat them up quickly to enjoy them while still hot. Farha tries to dissuade them from eating because they have just had breakfast and that it is not an appropriate hour for eating, but in vain. Shortly after, Farha sees "four huge feelers grow on their heads. She was scared and retired to her room, weeping quietly as she was overwhelmed by pain and grief"(Bakr 83).

(An Ecofeminist Reading of Salwa Bakr's...) Dr. Ebtesam El Shokrofy 
Psychologically, such pain and grief turn to a continuous scaring nightmare where all people appear to be worms for Farha. The most hilarious nightmare Farha has is that when she sees herself sitting in a green valley surrounded by all beauty and greenness and the golden fields of wheat. She is listening to the songs of birds and nightingales while enjoying the sight of colorful flowers. Then, suddenly:

A black cloud shaded the sky: She looked in the distance and saw colossal flabby worms, dull grey in colour, approach bit by bit until they crawled to the wide wheat field and devoured it in a second. They crossed to the trees and stripped them bare of all their verdant greenery. The birds flew away, singing sad, tearful tunes. When the worms reached the flower garden, they devoured the red and the blue and the yellow and the white and obliterated all things that brought joy to the eye and delight to the heart. Soon these creatures stood up like huge masses of limpid grey, with large human faces at the top (Bakr 82-3).

The faces Farha sees are those of her family and relatives who chase her in her dreams. Farha cries and laments the vanish of the beautiful nature, "Oh golden wheat. Oh, melodious birds. Oh, wondrous flowers. Oh breeze, Oh trees" (Bakr 82). These ugly faces, together with worms, symbolize man's harmful impact on nature and the absence of greenness and beauty.

(An Ecofeminist Reading of Salwa Bakr's...) Dr. Ebtesam El Shokrofy 
Such a beautiful nature captures Karima, whose life becomes tied to the life of trees and natural beauty around her. This plant metaphor symbolizes "The warmth and joy she seeks in an otherwise grey institutional world; the asylum with its filthy grey walls embodies the constriction and repression of authority which excludes those who deviate from the norm. As these trees are gradually cut down, Karimah develops nervous symptoms as if her own life were being destroyed with the trees" (Manisty 158). Such mutual love and belonging between Karima and the trees as well as Karima's stories about the trees and nature at a mass have an ecological ground in Gaard 's words: "We belong to the land as much as the land belongs to us, a belonging and identity that is articulated in the essentially narrative terms of naming and interpreting the land, of telling its story in ways that show a deep and loving acquaintance with it and a history of dialogical interaction"( 657). This mutual love between people and their environment is the joint message of both ecology and literature. Literature turns ecology to a lifestyle, to daily habits and practices that can be seen with the eyes of the ecologist. The interaction between nature and Bakr's characters turns positively into a more romantic dream in which each heroine dreams of a lover sharing her the love of nature and its beauty. Karima expresses such desire of having a young man who loves the city the way she does, who never gets tired of counting trees, who enjoys summer evenings under a clear sky. Unfortunately, Karima's dream turns into a nightmare when her lover wrongs her.

By the same token, Farha dreams of a gentle, quiet, lover who loves her differently: "he would talk to her gently as they listened to soft music; they might go out together to the park and walk in the middle of the trees and flowers,

(An Ecofeminist Reading of Salwa Bakr's...) Dr. Ebtesam El Shokrofy 
talking about the universe, the stars, the world full of people" (Bakr 81).Unfortunately, Farah's dream turns into an unremitting nightmare where she sees worms finishing up such beautiful nature. The lovers both Farha and Karima dream of exist only in their own dreams; they have no physical presence in such an ugly world. These lovers "felt threatened by the sense of freedom, spontaneity and individuality the women possess versus their own fake conservatism and blind subordination to the dominant discourse"(Sergius 28). The technique of using dreams in most of Bakr's short stories is another defense mechanism used by the female characters to escape their destiny. Thus, the search for a lover, for a new life, is, in fact a symbol of the wider search for beauty in society. In this way, Bakr's characters are individual cases standing for and representing many others. Here lies the idea of universality called for by ecofeminists who believe in the interconnectedness of all things. Ecofeminists see that personal actions and attitudes affect the whole community.

Ecofeminists' main concern is with the future - the coming generations. Women are always in charge of protecting their own lives, those of their children, and the life of the planet. Bakr uses children in most of her stories as her Fortinbras, her new coming hope for a better future. Karima is upset about the future of the children. She throws a stone into the brackish water by asking these questions:

How could I get married and give birth to children who would live in this city? How miserable they would be when they looked around them only to find a large forest cultivated with cement and the colors grey

(An Ecofeminist Reading of Salwa Bakr's...) Dr. Ebtesam El Shokrofy 
and brown. Furthermore, I was even more frightened for my grandchildren, for their predicament if they came into this world, lived in this city and never laid eyes on a flower, never even understood the meaning of the world (Bakr 125-6).

Karima's words echo cultural ecofeminists who stress the spiritual/ biological relation between women and nature where nature is portrayed as a mother caring for her children.

\section{Conclusion}

Bakr's "Thirty- one Beautiful Green Trees" and "Worms at the Flower Garden", are only examples of man's violation of the natural world which will never stop unless people change their attitudes to nature, unless they cooperate with their societies for betterment, unless they realize that individual actions affect the whole universe, and unless they appreciate women's real efforts to save nature. These principles are the main concern of ecofeminists who call for more empowerment of women because they are more capable than anyone else of protecting their children, families, society, and nature. Nothing is better than literature in conveying the message of ecofeminism. Literature turns the mere theories of ecofeminism to living experiences. One of the objectives of literature is to call for change. Writers as well as ecofeminists believe that people should change their negative attitudes to nature and restore the natural environment and quality of life for people and other living and non-living inhabitants of the planet. This is exactly women's message regarding nature. The ancient image of nature as a nurturing mother links women's history with the history of the environment and ecological change. The search

(An Ecofeminist Reading of Salwa Bakr's...) Dr. Ebtesam El Shokrofy 
for beauty of nature, especially by women, is a dominant theme in Bakr's works, with special reference to "Thirty- one Beautiful Green Trees" and "Worms at the Flower Garden". In her writings, Bakr is more concerned with common social issues than individual ones. She only focuses on particular female cases to refer to the entire social body. If ecofeminism flourishes during the 1970s, it is in the 1980s that a new wave of women writers in Egypt and the Arab World emerges giving voice to problems facing the vast majority of women by incorporating them into the map of literature. Bakr is considered one of the earliest women writers whose works open the door to an ecocritical literary analysis. To the best of my knowledge, this is the first paper to tackle any of Bakr's works from an ecofeminist point of view. Bakr's use of non-human images - parable of trees, gardens, flowers, worms, and fish, among many others to preach her convictions- relates her work safely to ecofeminism, as this paper attempts to show. In these selected short stories, Bakr employs Mary Mellor's seven ecological messages. She calls for a new beginning to free men and women from oppression and to be valued as equals. Equality, by turn, is the key for a just society. Changes regarding nature should be done for the welfare of all humanity because the individual actions affect the whole society and life, by and large. The rights of land, the rights of nature, and women's rights are all part of human rights. Finally, to value beauty is to value one's own life.

(An Ecofeminist Reading of Salwa Bakr's...) Dr. Ebtesam El Shokrofy 


\section{Works Cited}

Armbruster, Karla. "Book Reviews". NWSA Journal. vol. 12, no. 1, 2000. pp.10-16

Badry, Roswitha. "Socially Marginalised Women in Selected Narratives of Egyptian Female Writers". Studia Litteraria Universitatis Iagellonicae Cracoviensis 13 (2018), z. 4, s. 257

doi:10.4467/20843933ST.18.022.9475.www.ejournals.eu/Stu dia-Litteraria.

Bakr, Salwa. Such a Beautiful Voice. Contemporary Arabic Literature. Translated with an introduction by Hoda El Sadda. General Egyptian Book Organization,1992

Bennett, Barbara. "Through Ecofeminist Eyes: Le Guin's "the Ones Who Walk from Omelas". National Council of Teachers of English. The English Journal. vol. 94, no 6, 2005. pp. 62-68.

EL-Enany, Rasheed. "The Madness of Non-Conformity: Woman Versus Society in the Fiction of Salwa Bakr". Journal of Arabic Literature. vol.37, no. 3, 2006.pp. 376415.

Finzer, S., Erin. “Trees, Seas and Ecofeminist Imaginary in the Vanguard Poetry of Magda Portal (Peru, 19001989)'.Hispanofila. vol. 173, no (-), 2015. pp.319-332.

Gaard, Greta. "New Directions for Ecofeminism: Toward a More Feminist Ecocriticism". Interdisciplinary Studies in Literature and Environment. 17, no. 4,2010. pp.642665.

(An Ecofeminist Reading of Salwa Bakr's...) Dr. Ebtesam El Shokrofy 
Jaquette, Elisabeth. "Salwa Bakr on Women and Arabic Literature". Arablit Quarterly. Arabic Literature and Translation. 2012.doi: arablit.org/2012/11/18/Salwa-Bakr on-women-and-arabic-literature-2.

Kalita, Utpal. Ecofeminism: An Ethics of Environment.

Unpublished PhD Thesis. University of North Bengal. 2011. Bengal.

Manisty, Dinah. "Madness as Textual Strategy in the Narratives of Three Egyptian Women Writers". Alif: Journal of Comparative Poetics. vol. 14, no. (-), 1994.pp. 152-174.

Mellor, Mary. Feminism and Ecology. Cambridge:

Polity. 1997

--- "Feminism and Environmental Ethics: A Materialist Perspective". Ethics and the Environment. vol. 5, no. 1, 2000. pp.107- 123.

--- "New Woman, New Earth- Setting the Agenda". Organization \&Environment. vol.10, no, 3,1997. pp. 296308.

Merchant, Carolyn. Radical Ecology: The Search for a Livable World. Routledge, 2005, New York.

Sergius, Nermine. Narrative and Antinarrative: Resisting Oppression in Selected Works of Toni Morrison and Salwa Bakr. Unpublished MA Thesis. The American University, 2011. Egypt.

(An Ecofeminist Reading of Salwa Bakr's...) Dr. Ebtesam El Shokrofy 
Seymour-Jorn, Caroline. “A New Language: Salwa Bakr on

Depicting Egyptian Women's Worlds". Critique:

Critical Middle Eastern Studies. Vol. 11, no. 2, 2002. pp.151-176

Sinno, Nadine. "From Confinement to Creativity: Women's Reconfiguration of the Prison and Mental Asylum in Salwa Bakr's the Golden Chariot and Fadia Faqir's

Pillars of Salt'. Journal of Arabic Literature. vol. 42, no. (-), 2011. pp.67-94.

(An Ecofeminist Reading of Salwa Bakr's...) Dr. Ebtesam El Shokrofy 


\section{ملخص}

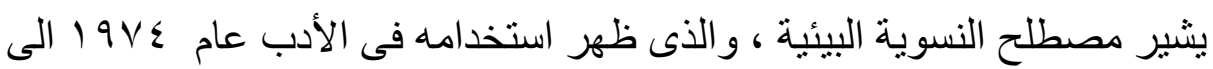

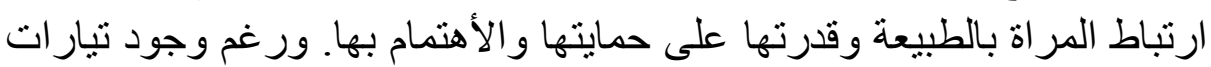

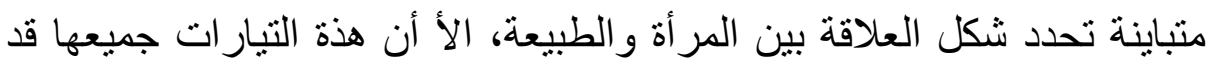

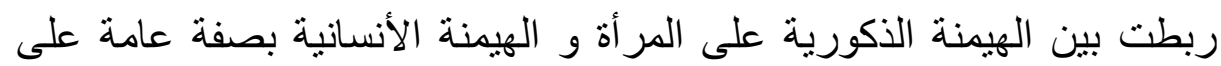

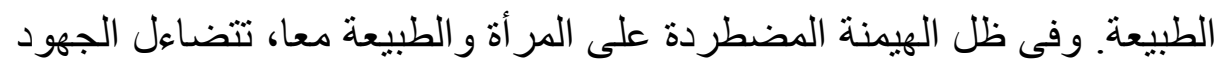

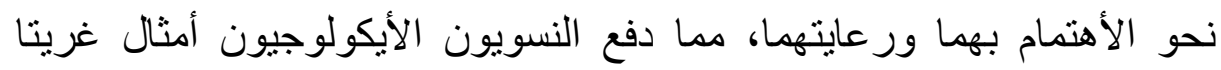

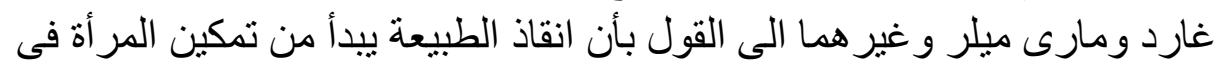

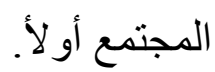

يتتاول هذا البحث قصتين قصيرثين للكاتبة سلوى بكر، تقدم من خلالهما

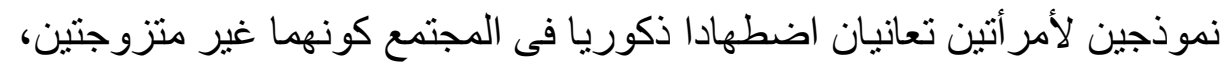

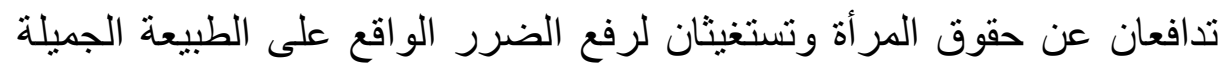

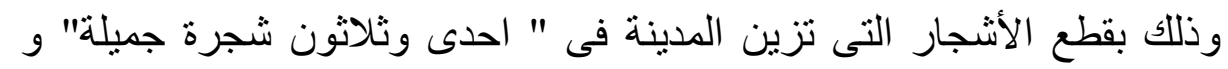

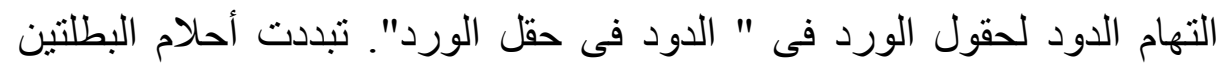

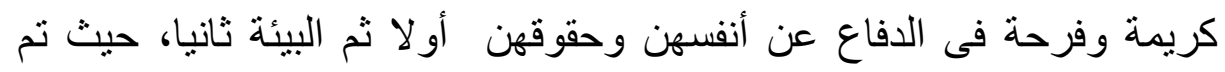
اتهامهما بالجنون ووضعهما فى احدى دور الافعاع العلاج النفسى.

ومن الناحية النظرية، يسعى الباحث جاهدا بين الربط بين نظريات النسوية

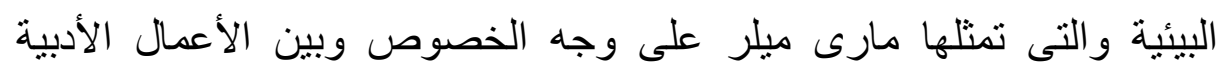
المختارة لسلوى بكر وذللك لتعزيز دور الأدب فى تناول مشكلات المر أة والبيئة

الكلمات المفتاحية: النسوية البيئية - ماري ميلور - سلوى بكر - دود في حديقة الزهور - واحد وثثلاثون شجرة خضراء المثلة جميلة

(An Ecofeminist Reading of Salwa Bakr's...) Dr. Ebtesam El Shokrofy 
(An Ecofeminist Reading of Salwa Bakr's...) Dr. Ebtesam El Shokrofy 408 